\title{
Economic Analysis of Corn Culture in Integrated Crop-Livestock-Forest System
}

\author{
Isabel Amalia Pereira Silva', Luciano Cavalcante Muniz', \\ Carlos Augusto Rocha de Moraes Rego ${ }^{2^{\star}}$, Ilka South de Lima Cantanhênde ${ }^{3}$, \\ Joaquim Bezerra Costa ${ }^{4}$, Juan López de Herrera ${ }^{5}$, Raabe Alves Souza ${ }^{1}$, \\ Victor Roberto Ribeiro Reis ${ }^{1}$, Eluardo de Oliveira Marques ${ }^{6}$, \\ Elimilton Pereira Brasil ${ }^{1}$ and Uelson Serra Garcia ${ }^{6}$ \\ ${ }^{1}$ State University of Maranhão, São Luis, Maranhão, Brazil. \\ ${ }^{2}$ State University of Western Paraná, Marechal Cândido Rondon, Paraná, Brazil. \\ ${ }^{3}$ Federal Institute of Maranhão, São Luis, Maranhão, Brazil. \\ ${ }^{4}$ Brazilian Agricultural Research Corporation (Embrapa Cocais), São Luis, Maranhão, Brazil. \\ ${ }^{5}$ Polytechnic University of Madrid, Madrid, Spain. \\ ${ }^{6}$ Federal University of Goiás, Goiânia, Goiás, Brazil.
}

\section{Authors' contributions}

This work was carried out in collaboration between all authors. All authors read and approved the final manuscript.

Article Information

DOI: $10.9734 / J E A I / 2018 / 40316$

Editor(s):

(1) Aleksander Lisowski, Professor, Department Agricultural and Forestry Engineering, Warsaw University of Life Sciences, Poland. Reviewers:

(1) Assem A. A. Mohamed, Egypt. (2) R. K. Mathukia, College of Agriculture, Junagadh Agricultural University, India. Complete Peer review History: http://www.sciencedomain.org/review-history/23957

Case Study

Received $19^{\text {th }}$ January 2018

Accepted $29^{\text {th }}$ March 2018

Published $4^{\text {th }}$ April 2018

\section{ABSTRACT}

Aims: Aim was to analyze the economic viability of an integrated crop-livestock-forest (ICLF) system area, in the municipality of Pindaré-Mirim, State of Maranhão, Brazil, using the consortium of maize (Zea mays L.), forage species Urochloa brizantha cv. Marandu and Eucalyptus (Eucalyptus urograndis).

Study Design: Case study.

Place and Duration of Study: The work was developed in a Technological Reference Unit of ICLF of Embrapa Cocais, located in the municipality of Pindaré-Mirim - Maranhão, Brazil, between 
January 2016 and July 2017 and The experimental area was 3 ha, divided into three subareas: Treatment I - single corn planting; Treatment II - Barreirão system; and Treatment III - Santa Fé system.

Methods: In this work, the method of operational costs was used. The following economic performance measures were calculated: Gross income (GI), Gross margin (GM), Net margin (NM), Profit, Leveling point (LP) and Rates of return (RR). The economic indicators calculated were: Net Present Value (NPV), Internal Rate of Return (IRR) and Benefit-Cost Ratio (RBC). The data collected from the costs and revenues of each treatment were tabulated and treated with the help of Microsoft Office Excel.

Results: All the treatments presented a profit, being the Barreirão System the one that had better results, presenting $P$ of 163 bags of maize ha ${ }^{-1}$, GI of US $\$ 1974$, profit of US\$780, LP in 99 bags, of $60 \mathrm{~kg}$, of corn ha ${ }^{-1}$ and RR of $65.33 \%$. Treatments I and III presented, respectively, P of 135 and 143 bags of maize ha ${ }^{-1}$, GI of US\$ 1635 and US\$1732, profit of US\$ 504 and US\$ 543, LP in 94 and 99 bags of corn ha ${ }^{-1}$ and RR of $44.63 \%$ and $45.67 \%$.

Conclusion: The results obtained reinforce the importance of studying the economic feasibility of ICLF system to provide the investor with the conditions for better decision making.

Keywords: Economic indicators; economic viability; integrated production systems.

\section{INTRODUCTION}

The integrated systems are being spread in various regions of Brazil as a viable alternative, and the Integrated Crop-Livestock-Forest (ICLF) system a production strategy that has no limitations on the size of the property or the technological level of farmers. The possibilities of combining the components of the system are many and the adjustments are necessary, depending on the objective of the producer, property features, edaphoclimatic and market [1].

The synergism between the components employed in the system assists in a better environmental suitability and economic viability of the agricultural activity of the property. The use of the ICLF system assists in the implementation of a sustainable agricultural system, based on the principles of rotation, succession and consortium between crops, forages and trees species, to produce grains, meat or milk and wood in the same area [2].

The ICLF system has contributed to a change in the land use system, based on the integration of the components of the production system, aiming to achieve higher levels of product quality [3]. Besides benefiting the biological interactions between agricultural crops, trees and animals, the ICL system reduce the effects of erosion, maintaining or increasing the reserves of organic matter in comparison with other agricultural models [4], thus allowing the rational use of land, in addition to providing higher yield per area than monoculture [5].
The multiple combinations of resources and activities provided by the ICLF systems make the decision to adopt them extremely complex, especially when a large part of the information disseminated does not include economic information [6]. Studying the economic viability of corn in the ILPF system, Rego et al. [7,8], find favorable results for the adoption of the system, obtaining a profitability in the first year of the ICLF system, even with the high costs in the implementation of the system.

The objective of this work was to analyze the economic viability of an ICLF system, in the municipality of Pindaré-Mirim, State of Maranhão, Brazil, using the consortium of maize (Zea mays L.), forage species Urochloa brizantha cv. Marandu and Eucalyptus (Eucalyptus urograndis).

\section{MATERIALS AND METHODS}

The study was developed at the Technological Reference Unit (TRU) for the ICLF of Embrapa Cocais, located in the municipality of PindaréMirim-MA (Brazil), Micro-region of Pindaré, at latitude coordinates $3^{\circ} 46^{\prime} 13.60^{\prime \prime} \mathrm{S}$, longitude $45^{\circ} 29^{\prime} 42.00^{\prime \prime} \mathrm{W}$, and with an altitude of $28 \mathrm{~m}$ above sea level. According to the classification of Koeppen [9], the local climate is AW type (hot and humid), with an average annual temperature of $299.15 \mathrm{~K}$ and average annual rainfall ranging from 1,600 to $2,000 \mathrm{~mm}$ $[10,11]$.

The soil class of the farm where the experiment was installed is classified as Hapless Plinth [12]. 
In relation to its relief, this one has variations of soft-waved to waved, being covered originally by vegetation of tropical forest subperenifolia dabótilo-palmácea babaçual, dominant in the Mid-North region of the State of Maranhão $[11,13]$.

The experiment was carried out in the agricultural year 2016/2017, in an experimental area of three hectares, divided into three subareas for the formation of the treatments. The treatments evaluated was: Treatment I Planting of single corn (monoculture); Treatment II - Barreirão System, is a technology for the recovery/renewal of degraded areas by the intercropping pasture consortium. The planting of corn intercropped with pasture was carried out. The planting of the pasture seed was carried out at the same time as the corn. The sowing of pasture is made between the lines of the maize. The mixture of the seeds of the grass is fertilized with (NPK) at the time of planting; Treatment III - Santa Fé System, is a technology consisting of the intercropping of annual crops, grains or forage, with forage species, mainly brachiaria, in partial or properly corrected soils. The planting of corn was carried out with intercropped pasture. Planting of the grazing seed was carried out at the same time as the maize crop, with no sowing between maize lines and no mixing of grass seeds with fertilizer (NPK).

For the implementation of the experiment, soil analysis was carried out throughout the area and fertilization recommendations were applied according to the soil analysis results (Table 1). A no-tillage system was used. Is a technique of conservationist cultivation, where sowing is carried out in a soil that is without the conventional tillage and no harrow. In this technique, it is necessary to keep the soil always covered by crops remains at least $80 \%$ of the soil surface or to maintain six tons per hectare of dry organic matter [14].
In all treatments, KWS 9304 hybrid corn was used, differing in the spreading of maize lines. In treatment I was used a spacing of $0.50 \mathrm{~m}$ between rows and $0.25 \mathrm{~m}$ between plants, and in the other treatments a spacing of $0.60 \mathrm{~m}$ between rows and $0.25 \mathrm{~m}$ between plants. For treatments II and III were used for the pasture seeds of Urochloa brizantha cv. Marandu, in order to establish a consortium according to the molds of the operations used.

In relation to the tree component used in the consortium, eucalyptus was used to provide income for the long-term system, animal welfare at the moment of grazing and source of organic matter and soil cover. In relation to the arrangement used for eucalyptus, these were planted in double rows spaced $3 \mathrm{~m} \times 2 \mathrm{~m}$ and 28 $\mathrm{m}$ long ( $3 \mathrm{~m}$ between rows, $2 \mathrm{~m}$ between plants), and they were planted in the first fortnight of February of 2016, the trees had approximately $2.5 \mathrm{~m}$ of height.

Corn planting was carried out on the straw of Urochloa brizantha cv. Marandu, which was desiccated with the pre-emergent herbicide, Glyphosate, in the dosage of $4.5 \mathrm{~L} \mathrm{ha}^{-1}$ and adhesive for drying up, in the dosage of $0.9 \mathrm{~L} \mathrm{ha}^{-}$ 1. Planting was carried out with the aid of a no-till planter with separate compartment for grass seed distribution. In planting, was used $400 \mathrm{~kg}$ $\mathrm{ha}^{-1}$ of NPK fertilizer (5 - 30-15 $\left.+\mathrm{Zn}\right)$, and their distribution grooves with a depth of $0.05 \mathrm{~m}$ and besides the corn seeds. The first cover fertilization was performed 10 days after emergence (DAE) of corn with $120 \mathrm{~kg} \mathrm{ha}^{-1}$ of urea and $85 \mathrm{~kg} \mathrm{ha}^{-1}$ of potassium chloride. In 15 $\mathrm{DAE}$, the application of the post-emergent herbicides Atrazine and Nicosulfuron, with a dosage of 3 and $0.5 L^{-1} a^{-1}$, respectively, was carried out for the initial control of pasture and broadleaf development. The second cover fertilization occurred 20 DAE with $200 \mathrm{~kg} \mathrm{ha}^{-1}$ of urea. In the 25 DAE, was applied of $3.5 \mathrm{~L} \mathrm{ha}^{-1}$ of Grap Nitro foliar fertilizer, $0.35 \mathrm{~L}^{-1}$ Abacus fungicide and $1.5 \mathrm{~L} \mathrm{ha}^{-1}$ Bazuka insecticide.

Table 1. Results of the soil analysis performed in the experiment implementation area, municipality of Pindaré-Mirim/MA, Brazil

\begin{tabular}{|c|c|c|c|c|c|c|c|c|c|c|c|}
\hline Prof. & M.O. & $\mathrm{pH}$ & $\mathbf{P}$ & $K$ & $\mathrm{Ca}$ & $\mathrm{Mg}$ & $\mathrm{H}+\mathrm{AL}$ & $\mathrm{Na}$ & $\mathrm{Al}$ & $\mathbf{H}$ & C \\
\hline $\mathbf{c m}$ & $\mathrm{g} / \mathrm{dm}^{3}$ & $\mathrm{CaCl}_{2}$ & $\mathrm{mg} / \mathrm{dm}^{3}$ & & ------ & |------ & $\mathrm{molc} / \mathrm{dm}$ & ----.. & $---\cdot$ & & $\mathrm{g} / \mathrm{dm}^{3}$ \\
\hline $0-20$ & 11 & 4.6 & 2.0 & 4.4 & 32.0 & 13.0 & 23.0 & 7.4 & 0.0 & 23.0 & 6.1 \\
\hline
\end{tabular}


In this work, the method of operational costs was used, according to Matsunaga et al. [15] and Lopes et al. [16]. The following economic performance measures were calculated: Gross income, Gross margin, Net margin, Profit, Leveling point and Rates of return, according to method of Martin et al. [17] and Rego et al. [7]. The economic indicators calculated were: Net Present Value (NPV), Internal Rate of Return (IRR) and Benefit-Cost Ratio (RBC), according to the method of Evangelista [18] and Muniz et al. [19]. The data collected from the costs and revenues of each treatment were tabulated and treated with the help of Microsoft Office Excel.

\section{RESULTS AND DISCUSSION}

Table 2 present costs, revenues and economic efficiency indicators for the implantation of one hectare of corn in the municipality of PindaréMirim - MA.

The percentage of the Total Cost (TC) that represents the Effective Operating Cost (EOC) is $70.23 \%$ for treatment I, $71.51 \%$ for II and $71.42 \%$ for III. Because the EOC represents the majority of the costs of the initial acquisition of inputs required for production. These results are well below those reported by Rego et al. $[7,8]$ for all the evaluated systems, indicating that there is a decrease in EOC, which is explained by the purchase of inputs carried out in partnership with other producers, which resulted in a higher discount on the price of inputs.
Regarding the composition of the total operating cost (Table 2), taking into account depreciation and producer remuneration, these corresponded to only $19.26 \%, 18.24 \%$ and $18.31 \%$ of TC, respectively, for treatments I, II and III per hectare. The opportunity cost found for treatments I, II and III were $10.51 \%, 10.25 \%$ and $10.27 \%$ of TC, respectively.

The TC of 1 hectare of maize according to data obtained by the Instituto Mato-Grossense de Economia Agropecuária, IMEA, [20], for the Northeast region of Brazil, is US\$ 773 and US\$ 652 with the high and medium investment technology respectively. In our case (Table 2), the TC of the three Treatments were higher. Evaluating the implantation of the ICLF system, the high TC for the study region in all treatments is justified by the predominance of livestock farming in the region of Pindaré-Mirim according to Rego et al. [8]. Some factors influence such as the high costs of the acquisition of inputs and the lack of machines for agricultural activity. In addition, the region does not have its own local distribution center, and the producer has to pick them about $300 \mathrm{~km}$ away from the property.

In relation to productivity (Table 2 ), treatment II was the highest productivity, with 163 bags per hectare, followed by treatment III with 143 bags and treatment I with 135 bags. The productivity found for all treatments was higher than that estimated by Conab [21], for the state of Maranhão in the 2016/2017 harvest, which was 70 bags per hectare and was similar to that found by Teixeira et al. [22].

Table 2. Total costs, revenues and indicators of efficiency for maize among different treatments in between January 2016 and July 2017 (one hectare)

\begin{tabular}{llll}
\hline Discrimination & \multicolumn{3}{c}{ Treatments } \\
\cline { 2 - 4 } & I & II & III \\
\hline Operational Cost - US\$/ha/year & 794 & 854 & 849 \\
Depreciation - US\$/ha/year & 53 & & \\
Remuneration of the producer - US\$/ha/year & 165 & & \\
Total Operating Cost - US\$/ha/year & 1012 & 1072 & 1067 \\
Opportunity Cost - US\$/ha/year & 118 & 122 & 122 \\
Total Cost - US\$/ha/year & 1131 & 1194 & 1189 \\
Productivity (60 kg bags / ha) & 135 & 163 & 143 \\
Price of the bag - US\$ & 12.11 & & \\
Leveling point (Total cost/price of bag) & 94 & 99 & 99 \\
Gross income (Price of the bag * Productivity) - US\$/ha/year & 1635 & 1974 & 1732 \\
Gross Margin - US\$/ha/year & 841 & 1120 & 883 \\
Net Margin - US\$/ha/year & 623 & 903 & 665 \\
Profit - US\$/ha/year & 504 & 780 & 543 \\
Rate of return - in \% & 44.63 & 65.33 & 45.67 \\
Benefit / Cost Ratio & 1.45 & 1.65 & 1.46 \\
\hline
\end{tabular}


For the agricultural year of 2017 the selling price of the $60 \mathrm{~kg}$ maize bag was US\$12.11 and according to the yields obtained, treatment II due to its higher productivity presented higher gain financial followed by treatments III and I. Analyzing the economic viability of the implementation of an ICLF system for the agricultural year 2015/2016, Rego et al. [8] obtained similar results in relation to yield and profitability of the integrated systems in relation to single maize cultivation.

In relation to the leveling point (Table 2), which is the level of production in which the sales value equals the total cost, in all treatments were found values above the minimum, that is, all treatments had positive profit for the adoption of any of the systems analyzed. This results corroborate with those found by Rego et al. [8] and Teixeira et al. [22] and can serve as the basis for the ICLF system's recommendation.

To gross margin (Table 2) in all treatments were positive, indicating that productivity obtained for each treatment sufficient to cover production costs. The net margin (Table 2) for each treatment was positive, meaning that the adoption of any of the productive systems has stable activity, allowing the expansion of the activity.

Regarding the profit margin results (Table 2) found by treatment, all were positive, meaning that the producer is paying all costs. Treatment II was the one with the highest profit margin per hectare. However, all the treatments obtained gains per hectare, having paid the formation of the pasture that will serve as complementary income in the off-season moments.

When a positive result is obtained for the profit margin, according to Rego et al. [8], this indicates that the producer will be able to maintain itself in the long term, besides honoring its commitments, serving as an indicator of equilibrium which it compensates all factors of production.

Treatment II obtained the highest rate of return (Table 2) with $65.33 \%$, followed by treatments III and with $45.67 \%$ and $44.63 \%$, respectively. This indicator indicates the financial return that the producer can obtain if invests in any of the treatments analyzed. These results differ from those reported by Rego et al. [8], where the conventional corn system indicated a better rate of return, but are similar to those found by Teixeira et al. [22]. The results obtained in the present work indicate that the ICLF system for the Pindare-Mirim region, after the first year of implantation, is more advantageous than the introduction of maize monoculture.

The benefit-cost ratio (RBC) (Table 2) for all treatments was greater than one, which means that any management system employed will bring financial benefits that exceed production costs. These results resemble those found by Teixeira et al. [22]. RBC is consistent as a method for defining decisions to strategically achieve relevant data about desirable and undesirable outcomes. In this way it is possible to measure these elements in a comparative way, thus controlling for the cost to not exceed the benefits [23].

According to Marquezan [24], seeking a profitable and sustainable return is the basis of the reasons for the realization of investments with wealth generation, so that there is value or wealth creation, the costs of the capital employed must be lower than the returns of these investments, making the net values of the results positive, adding wealth to the investor and to the investment itself.

Table 3 shows the results for the net present value with the different minimum rate of attractiveness (ARM) for the implantation of the treatments. According to Casarotto and Koppitke [25], the ARM represents the attractive rate that investors expect to obtain from a project and that is equivalent to the profitability of other applications, that is, it is an interest rate that represents the minimum that an investor proposes when he makes an investment.

Table 3. Statement of net present value

\begin{tabular}{llll}
\hline ARM, \% & \multicolumn{3}{c}{ Treatment (UU\$) } \\
\cline { 2 - 4 } & I & II & III \\
\hline 6 & 412 & 668 & 445 \\
19 & 243 & 465 & 266 \\
27 & 157 & 360 & 175 \\
40 & 37 & 216 & 48 \\
45 & -3 & 167 & 6 \\
46 & -11 & 158 & -3 \\
66 & -145 & -5 & -146 \\
\hline
\end{tabular}

The results of the NPV indicate that it is favorable to adopt any treatment because the values obtained are higher than the rate of the attractiveness of the savings card, about $6 \%$ per annum. This indicates that the investor can opt for any of the treatments because there will be benefits financial. 
Table 4 shows the results of the internal rate of return (IRR) for all treatments. The IRR is the percentage that the investor expects to earn by assigning resources in a project, the interest rate that makes the net present value zero. Maya [26] states that the IRR is a useful indicator for analyzing high initial investments and that contribute to production for several periods of time, as is common in agricultural enterprises.

Table 4. Internal rate of return statement

\begin{tabular}{llll}
\hline & \multicolumn{3}{c}{ Treatment } \\
\cline { 2 - 4 } & I & II & III \\
\hline IRR & $39.27 \%$ & $60.43 \%$ & $40.24 \%$ \\
\hline
\end{tabular}

\section{CONCLUSION}

The economic indicators of all treatments obtained positive results. The ICLF system, following the model of the Barreirão system, obtained better economic results than the others. Regarding NPV and IRR in all treatments, the results were positive, with superior attractiveness to the savings account investment. This shows that the integrated systems obtained higher returns on invested capital and profitability compared to the single system for the study region.

This research reaffirms the importance of continuing in studies within the ICLF production system, not only to prove its economic viability but also for other parameters regarding quality, soil health, cost and risk reduction, livelihood security and environmental protection.

\section{ACKNOWLEDGEMENTS}

The authors thank the Scientific Initiation Program of the State University of Maranhão for the scientific initiation grants, sponsored by the Foundation for Scientific and Technological Research and Development of Maranhão (FAPEMA), the National Council for Scientific and Technological Development (CNPq) and Coordination for the Improvement of Higher Education Personnel (CAPES).

\section{COMPETING INTERESTS}

Authors have declared that no competing interests exist.

\section{REFERENCES}

1. Gontijo Neto MM, Viana MCM, Alvarenga RC, Santos EA, Simao EP, Campanha
MM. Systems of crop-livestock-forest integration in Minas Gerais. Animal Industry Bulletin. 2014;71(2):183-191.

2. Balbino LC, Barcellos AO, Stone LF. Reference frame: Crop-livestock-forest integration. Brasília: Embrapa. 2011;130.

3. Kaminski TH. Nitrogen residual effect applied in winter for maize cropping in a crop-livestock integration system. 2013. 58 f. Dissertation (Master's Degree in Concentration and Plant Production) State University of Central-West (UNICENTRO). Guarapuava; 2013.

4. Aguiar MI, Maia SMF, Xavier FA, Mendonça ES, Araújo Filho JA, Oliveira TS. Sediment, nutrient and water losses by water erosion under agroforestry systems in the semi-arid region in northeastern Brazil. Agroforestry Systems. 2010;79:277289.

Available:https://doi.org/10.1007/s10457010-9310-2

5. Souza LSB, Moura MSB, Sediyama GC, Silva TGF. Efficiency of water use of maize and cowpea crops under exclusive and intercropping systems in the Brazilian semi-arid region. Bragantia. 2011;70:715721.

6. Costa FP, Almeida RG, Pereira MA, Kichel AN, Macedo MCM. Economic evaluation of crop-livestock-forest integration systems aimed at the recovery of degraded areas in Mato Grosso do Sul. VII: Latin American Congress of Agroflores Systems for Sustainable Livestock Production; 2014.

7. Rego CARM, Reis VRR, Wander AE, Cantanhêde ISL, Costa JB, Muniz LC, Costa BP, Herrera JL. Cost analysis of corn cultivation in the setup of the croplivestock-forest integration system to recover degraded pastures. Journal of Agricultural Science. 2017;9(6):168-174. Available:https://doi.org/10.5539/jas.v9n6p 168

8. Rego CARM, Muniz LC, Reis VRR, Cantanhêde ISL, Costa BP, Marques EO, Oliveira PSR. Economic analysis of the implantation of different crop-livestockforest integration systems in the municipality of Pindaré-Mirim, Maranhão. Sodebras. 2018;13(146):114-118.

9. Köppen W, Geiger R, Klimate der Erde W. Climate Classification System - SCC; 1948.

10. Alvares CA, Stape JL, Sentelhas PC, Gonçalves JLM, Sparrovek G. Köppen's climate classification map for Brazil. 
Meteorologische Zeitschrift. 2014;22:711728.

Available:https://doi.org/10.1127/0941-

2948/2013/0507

11. SEPLAN. Atlas of Maranhão. Secretary of State for Planning and Budget, Geoenvironmental Nucleus - UEMA. São Luís: SEPLAN. 2013;90.

12. Santos HG, Jacomine PKT, Anjos LHC, Oliveira VA, Lumbreras JF, Coelho MR, Almeida JA, Cunha TJF, Oliveira JB. Brazilian system of soil classification. 3.ed. Brasilia: EMBRAPA. 2013;353.

13. MARANHÃO. Coastal zoning of the State of Maranhão. State Management of Agriculture, Livestock and Rural Development - GEAGRO, UFMA, São Luís: Sousandrade Foundation, 2003;253.

14. Cruz JC, Alvarenga RC, Viana JHM, Filho IAP, Filho MRA, Santana DP. Direct planting system. Embrapa Agency of Technological Information. Direct Planting; 2017.

(Acessed em: 20 January 2018)

Available:http://www.agencia.cnptia.embra pa.br/gestor/milho/arvore/contag01 $72 \quad 59$ 200523355.html

15. Matsunaga $\mathrm{M}$, Bemelmans PF, Toledo PEN, Dulley RD, Okawa H, Pedroso IA. Methodology of cost of production used by the IEA. Agriculture in São Paulo. 1976;23:123-139.

16. Lopes MA, Lima ALR, Carvalho FM, Reis RP, Santos IC, Saraiva FH. Managerial control and profitability study of milk production systems in the region of Lavras (MG). Science and Agrotechnology, 2004;28(4):883-892.

Available:http://dx.doi.org/10.1590/S141370542004000400022

17. Martin NB, Serra R, Oliveira MDM, Ângelo JÁ, Okawa H. Integrated system of agricultural costs - CUSTAGRI. Economic Information. 1998;28:7-28.

18. Evangelista MLS. Comparative study of investment analysis in projects between the vpl method and the real options: The cooperative credit case - Sicredi Noroeste. 163 f. Thesis (Doctorate), Federal
University of Santa Caratina, Florianópoles; 2006.

(Acessed in 20 January 2018)

Available:http://www.bertolo.pro.br/matema tica/Tese\%20de\%20Doutorado\%20UFSC. pdf

19. Muniz LC, Figueiredo RS, Magnabosco $\mathrm{CU}$, Wander AE, Martha Junior GB. Economic analysis of crop and livestock integration using system dynamics. In: XLV Congress of the SOBER, Londrina-PR, July 22 to $25 ; 2007$.

20. IMEA. Mato Grosso Institute of Agricultural Economics. Annual Reports of Production Cost of Maize 2016/ 2017.

(Acessed in: 20 January 2018)

Available:http://www.imea.com.br/site/princ ipal.php

21. CONAB. National Supply Company. Follow up of the Brazilian grain crop, Safra 2016/17 - Tenth survey, Brasília. 2017;4:1171.

22. Teixeira LP, Melo RACE, Vilela L, Balbino LC, Cordeiro LAM. Economic viability of crop-livestock-forest integration (iLPF): Study in Ipameri-GO. Society and Rural Development. 2012;6(2):1-23.

23. Dias J. Learn how to use cost-benefit analysis in project evaluation; 2014.

(Acessed in: 20 January 2018)

Available:http://blogdaengenharia.com/apr enda-usar-analise-custo-beneficionaavaliacao-de-projetos/

24. Marquezan LHF. Analysis of investments. Revista Eletrônica de Contabilidade Course of Accounting Sciences, Santa Maria. 2006;3(1):1-15.

Available:http://dx.doi.org/10.5902/198109 466137

25. Casarotto Filho N, Kopittke BH. Investment analysis. 9. ed. São Paulo: Atlas; 2000.

26. Maya FLA. Productivity and economic viability of cattle rearing and fattening in pastures intensively fertilized with and without irrigation. 2003. 83f. Dissertation (Master in Animal Science and Pasture) Luiz de Queiroz College of Agriculture (ESALQ) - University of São Paulo, Piracicaba; 2003.

(c) 2018 Silva et al.; This is an Open Access article distributed under the terms of the Creative Commons Attribution License (http://creativecommons.org/licenses/by/4.0), which permits unrestricted use, distribution, and reproduction in any medium, provided the original work is properly cited.

Peer-review history:

The peer review history for this paper can be accessed here: http://www.sciencedomain.org/review-history/23957 